IZA DP No. 9349

Environmental Disasters and Migration

Linguère Mously Mbaye

Klaus F. Zimmermann

September 2015

Forschungsinstitut zur Zukunft der Arbeit Institute for the Study of Labor 


\title{
Environmental Disasters and Migration
}

\author{
Linguère Mously Mbaye
}

IZA

Klaus F. Zimmermann

IZA and Bonn University

\section{Discussion Paper No. 9349 \\ September 2015}

\author{
IZA \\ P.O. Box 7240 \\ 53072 Bonn \\ Germany \\ Phone: +49-228-3894-0 \\ Fax: +49-228-3894-180 \\ E-mail: iza@iza.org
}

Any opinions expressed here are those of the author(s) and not those of IZA. Research published in this series may include views on policy, but the institute itself takes no institutional policy positions. The IZA research network is committed to the IZA Guiding Principles of Research Integrity.

The Institute for the Study of Labor (IZA) in Bonn is a local and virtual international research center and a place of communication between science, politics and business. IZA is an independent nonprofit organization supported by Deutsche Post Foundation. The center is associated with the University of Bonn and offers a stimulating research environment through its international network, workshops and conferences, data service, project support, research visits and doctoral program. IZA engages in (i) original and internationally competitive research in all fields of labor economics, (ii) development of policy concepts, and (iii) dissemination of research results and concepts to the interested public.

IZA Discussion Papers often represent preliminary work and are circulated to encourage discussion. Citation of such a paper should account for its provisional character. A revised version may be available directly from the author. 
IZA Discussion Paper No. 9349

September 2015

\section{ABSTRACT}

\section{Environmental Disasters and Migration ${ }^{*}$}

This paper reviews the effect of environmental disasters on migration. Although there is an increase of environmental disasters and migration over the past years, the relationship is complex. While some authors find that environmental disasters increase migration, others show that they have only a marginal or no effect or are even negative. Migration appears to be an insurance mechanism against environmental shocks. Remittances help to decrease households' vulnerability to shocks but also dampen their adverse effects. Finally, we discuss policy implications and future research avenues.

JEL Classification: J61, O15, Q54, Q56

Keywords: environmental shocks, forced migration, remittances, migration as insurance, floods, earthquakes, droughts

Corresponding author:

Klaus F. Zimmermann

IZA

P.O. Box 7240

53072 Bonn

Germany

E-mail: zimmermann@iza.org

\footnotetext{
*We thank Victoria Finn for editorial suggestions.
} 


\section{Introduction}

Environmental disasters are often considered an important driver of migration. However, historical evidence shows that this relationship is not new and has probably existed since the beginning of human history. Nevertheless, the reactions are not well documented and the implications not yet fully understood, although the incidences of environmental disasters and migration seem to have increased. This is likely to become more relevant in the long run with global warming. Analyzing the short-term implications and the possible adjustment mechanisms is important, since this enables the introduction of reaction mechanisms to better deal with the consequences of a crisis. For instance, the migration response to an environmental disaster is complex, it can be strong, moderate or even negative. The focus of this paper will therefore be on the short-term aspects of our topic.

The relationship between environmental disasters and migration is possibly one of the biggest challenges that future generations will face. Why is the relationship between natural disasters and migration so controversial? What are the consequences of migration decisions following environmental disasters? This paper provides an overview of the literature on these two specific points. The effect of environmental disasters on migration is crucial because it has serious implications on economics, demography, and sociology. Subsequently, we draw on literature in these three areas.

The paper is structured as follows. Section 2 defines the topic and documents empirical trends. Section 3 explores the migration decision under the occurrence of environmental disasters. Section 4 presents the role of migration as an insurance mechanism when disaster occurs. Section 5 discusses the consequences of the environmental disaster migration decision. More precisely, we assess if migration and associated remittances can help mitigate the environmental disasters' negative consequences, as well as the consequences in terms of other outputs. The last section presents the concluding remarks. 


\section{The research issue and empirical trends}

A good reference introducing into the historical dimension of the topic is provided by Belasen and Polachek (2013), while we focus here more on historical empirical evidence since the mid$19^{\text {th }}$ century to more recent events. Gottschang (1987) documented migration driven by natural disasters such as floods and droughts in Northern China and Manchuria from 1890 to 1942. Boustan et al. (2012) use panel data from 1920 to 1940 in the United States (US) and consider disasters such as floods, tornadoes, earthquakes and hurricanes in a context where migration is a self-protection mechanism. They show that young men leave areas affected by tornados to settle in areas affected by floods. In the same country during the 1930's, Hornbeck (2012) documented how the Dust Bowl, caused by severe drought and intensive land use, had serious consequences on population decline in areas with high and medium erosion areas between 1930-1950. Cross (2013) examines the period 1992-2008 to see how US communities deal with natural disasters such as storms, hurricanes, river flooding and tornadoes in terms of demographic changes. He found post-disaster relocation and that small communities lose more population. This effect is related to the communities' level of wealth. Hurricane Katrina in 2005 was the major recent disaster that heavily impacted the US (Gutmann and Field, 2010; Vigdor, 2008). It induced the migration of 10,000 people in 26 states of the United States.

From examples in Central America and the Caribbean, based on a study from 1980 to 2009 Afonso (2011) shows that severe tropical storms induce migration. Hanson and McIntosh (2012) are interested in migration between 25 Latin American and Caribbean countries and Canada, Spain, the US and the UK from 1980-2005. They found that labor supply, demand shocks and natural disasters are push factors for migration from Latin America to the US while this is not the case for migration to the other countries.

Furthermore, both developed and developing countries are already dealing with an increase in the severity of disasters and their effects. Figures related to natural disasters are both 
impressive and alarming. In developing countries such as Indonesia, a tsunami caused 500,000 victims in 2004 (Smith, 2007). Although the number of victims due to disasters decreased compared to the decade 1990-2000, it still remains high. According to the Annual Disasters and Statistical Review 2012 (Guha-Sapir, 2013), the annual average number of victims by natural disasters between 2000 and 2011 is estimated at 268 million people around the world. Economic costs were estimated at 143 million USD in 2012.

The attached figures from the online appendix provided by Drabo and Mbaye (2013) provide recent empirical evidence The graphs show the trends of both natural disasters and migration from 1975 to 2000 with a focus on developing countries. For all regions of the world, natural disasters and migration exhibit an increasing trend over the period. The only exception was for Central Europe and Central Asia, where there was a decrease before 1990 but an increase then followed.

The Centre for Research in Epidemiological Disasters (CRED) considers all disasters subgroups of extra-terrestrial disasters. Consequently, the term environmental disasters include those that are geophysical (earthquake, mass movement, volcanic activity), meteorological (extreme temperature, fog, storm), hydrological (flood, landslide, wave action), climatological (glacial lake outburst, wildfire), and biological (epidemic, insect and animal infestation).

In the literature, different types of variables have been considered that pertain to the relationship between environmental factors and natural disasters. For instance, Reveuny and Moore (2009) found that environmental degradation, including both storms and land scarcity, increases out-migration. Other studies showed that weather anomalies measured through longterm deviations of rainfall and temperature are a migration determinant in Sub-Saharan Africa (Barrios et al., 2006; Marchiori et al., 2012). Beine and Pearsons (2014) are interested both in long-term environmental factors with the use of rainfall and temperature data and short-term variables measured through natural disasters. 
In this paper, we use the CRED’s natural disasters definition, which relates to short-term shocks, and we also consider a broader concept of disasters that includes weather anomalies in a long-term perspective.

\section{Environmental disasters and migration: a controversial relationship}

To date, there is no consensus on the impact of natural disasters on migration. Some studies show that negative environmental factors increase migration. Reuveny and Moore (2009) highlight the positive effect of environmental degradation on migration to developed countries. Drabo and Mbaye (2013), based on a study that focuses on developing countries, show that natural disasters mainly related to climate change increase overall migration. They specify in their study that this effect is driven by the most educated people, who can afford migration costs. However other analyses such as studies by Black (2001) and Piguet and Pecoud (2011) highlight the need to relativize the scope of the natural disaster effect on so-called environmental refugees. The mixed evidence related to the role of disasters on migration is probably due to the fact that this relationship is complex and less straightforward than perceived by common knowledge. Naudé (2010) and Beine and Parsons (2014) do not find a direct effect of natural disasters on migration but rather an indirect effect. Indeed, they argue that disasters affect migration from Sub-Saharan Africa by inducing conflicts and negatively affecting Gross Domestic Product (GDP).

Some studies find that environmental factors lead to both internal and international migration. This holds true for Marchiori et al. (2012), who find that weather anomalies may cause both internal and international migration in Sub-Saharan Africa. However, other studies show that seasonal and circular migration are more common than international mobility in the case of environmental shocks. Gray (2009) uses empirical evidence from Ecuador and shows 
that adverse environmental conditions do not necessarily increase out migration but do have an effect on internal migration.

This has been confirmed by Beine and Parsons (2014) in a macroeconomic study; however, this internal effect depends on regions. For instance, Barrios et al. (2006) find an increasing effect of climate variables on internal migration only in Sub-Saharan Africa. On the other hand, Deng (2011) explores the relationship between natural disasters and urban insecurity in China with rural-urban migration as a channel. Using Chinese data from 2002, her findings show that while natural disasters only slightly increase migration, they impact the composition of migrants in a structural way. Natural disasters force rural inhabitants to move while they would have stayed without the occurrence of these shocks. Moreover, in terms of wage, they earn less in urban areas than their counterparts, which may lead to an increase of urban insecurity.

Different types of disasters can cause different types of migration. Using multivariate events-history models with panel data from Bangladesh from 1994 to 2003, Gray and Mueller (2011) show that on the one hand, floods have only marginal effects on migration. However, they mainly affect women and the poorest are not necessarily the most affected. On the other hand, crop failures highly influence migration. Finally, they suggest that natural disasters related to climate do not necessarily have an increasing effect on overall migration but can have a long-term effect on migration of rural populations.

Nonetheless, other evidence highlights the fact that long-term migration responds less to natural disasters than short-term migration. Henry et al. (2004) and Findley (1994) show in the case of West Africa (Burkina Faso and Mali, respectively) drought causes temporary and permanent migration to rural areas that have higher levels of rainfall. However, this effect depends on the destination and duration of migration. More generally it is even possible that disasters reduce migration. Halliday (2006) shows that in El Salvador, earthquakes decrease migration prospects by limiting access to savings and credits. The negative effect of disasters 
on migration is also due to the fact that public investment in affected areas can dampen the effect of self-protection mechanisms such as migration or because labor demand increases in affected areas (Boustan et al., 2012; Henri et al., 2004; Gray and Mueller, 2011).

\section{Migration as an insurance mechanism to environmental disasters}

Migration is a coping mechanism against shocks (Stark and Levhari, 1982; Rosenzweig and Stark, 1989). The New Economics of Labor Migration literature developed the idea of migration as a strategy of risk diversification. For instance, according to Stark and Levhari (1982), risk aversion is the main cause of rural to urban migration in developing countries. Indeed, rural families who have to deal with agricultural production risks may send a member to migrate to urban areas in order to diversify the household's income sources. Consequently, when disasters increase vulnerability, people have to find coping mechanisms and migration is one of them.

Vulnerability is one of the channels that can explain the relationship between environmental shocks and migration. Carter et al. (2007) study severe environmental shocks' long-run economic impact in Ethiopia and Honduras. They find that these shocks severely affect the most vulnerable people, who can be caught into poverty traps. Poor households are thus put in a vicious circle. Since they are more vulnerable, they fall into poverty more easily than wealthier households and subsequently, this situation increases their vulnerability. The latter affects different groups in different ways. For instance, studies showed that women are more vulnerable to disasters (Enarson, 2000). Neumayer and Plümper (2008) focus on how natural disasters affect the gender gap in life expectancy. From an analysis based on 141 countries over the period 1981 to 2002, they show that natural disasters decrease life expectancy of women compared to men. This effect is persistent with the intensity of the disasters. Put differently, the 
natural disaster effect on the gender gap life expectancy increases with shock intensity. Countries where women have good socioeconomic status tend to have a lower effect of disasters on the gender gap life expectancy.

Schultz and Elliott (2012) use census and environmental hazards data from the US in the 1990s to show that disasters are positively associated with changes in local population growth and housing. Furthermore, post-disaster recovery can be at the origin of polarization in the socioeconomic structure of affected areas. Put differently, families at the top of the income distribution would positively benefit from these shocks while there would be no decrease in the number of poor in the communities.

There are other factors beyond vulnerability and inequality which can be considered as transmission channels between shocks and disasters. Arouri et al (2015) use fixed effects at the commune level to assess the effect of natural disasters on poverty and welfare in rural Vietnam. Considering floods, storms, and droughts, they find that all of these negatively affect household expenditures and income. However, while these studies suggest that environmental shocks can affect migration through different channels, other studies show that this is not necessary always the case. Ghimire et al. (2015) compiled historical data on civil conflicts, large floods and displacement from 126 countries over the period 1985 to 2009. They show that migration due to large floods is not at the origin of new conflicts. However it can exacerbate existing conflicts, above all in developing countries, although this effect does not last overtime.

\section{Consequences of migration decisions following disasters: the role of remittances}

In this part, we draw on the literature that assesses how migration can reduce the adverse effects of environmental disasters, particularly through remittances. Remittances are critical in dealing with natural disasters, both during the disaster and in the aftermath (Fagen, 2006). 
Indeed, compared to non-recipients, remittance receivers show decreased vulnerability to disasters and have better opportunities to deal with them (Savage and Suleri, 2006). AmuedoDorantes et al. (2011) are interested in the impact of natural disasters, foreign development aid and real exchange rates on remittances in the context of Small Islands Developing States. Using Panel VAR methods to deal with endogeneity issues, they found that both remittances inflows and foreign aid are positively responsive to natural disasters. Migrants clearly show altruistic behavior when their left-behind relatives have to deal with adverse negative shocks. At the same time, they show that remittances tend be substitutable to other inflows such as foreign aid.

In another study, Mohapatra et al. (2012) look at remittances in the aftermath of natural disasters such as floods, earthquakes and droughts. They are also interested in examining if remittances help to prepare for future disasters. Using both macro and microeconomic analysis, they show that remittances are positively correlated with natural disasters in origin countries that have a high share of migrants relative to the total population. This positive effect of remittances is demonstrated in the ex-ante preparation of natural disasters, particularly from high-income countries since they are much larger amounts compared to internal migration transfer flows. Remittances also positively benefit households in responding to adverse environmental shocks. More specifically, evidence from Burkina Faso and Ghana show that those receiving remittance from OECD countries have better coping strategies for natural disasters because migrants' transfers provide them with opportunities to live in concrete houses and have easier access to means of communication. In Ethiopia, international remittance receivers can rely more on inflows than on household assets to insure food security in the case of shocks. Finally the example of Bangladesh shows that in the aftermath of a flood in 1998, per capita household consumption was higher for remittance receivers.

Although natural disasters are cited among the determinants of remittances volatility (Jackman, 2013), in addition to the study of Mohapatra et al. (2012), other analyses show that 
remittances help dampen environmental disasters’ negative effects. For instance, Arouri et al. (2015) found that internal remittances help make households more resilient to natural disasters. Yang and Choi (2007) use rainfall shocks as instrumental variables to assess the relationship between remittances and income variations in the Philippines. They find that international remittances fulfill an insurance role during income shocks, with the replacement rate almost equal to $100 \%$. Finally, from a sample of 113 developing countries over the period 1980 to 2007, Combes and Ebeke (2013) find that while natural disasters increase output growth volatility, remittances attenuated disasters’ marginal destabilizing impact. However, this effect is not linear. For remittances rationed between 8 and 17\% of GDP, the dampening effect of migrants' transfers is maximized. However in this same interval, remittances increase the instability due to disasters.

\section{Concluding remarks}

Both developing and developed countries have to deal with environmental disasters. Migration plays an insurance role when households face adverse shocks. Moreover, due to remittances, migration helps those left-behind to cope with disasters. The overview of the literature allows understanding why the relationship between environmental disasters and migration is so controversial and why a consensus is so difficult to find in the literature. Indeed, while some studies find that environmental disasters increase migration, others find that they decrease it or do not even have any impact on migration. It has also been found that the effect of environmental disasters on migration depends on the type of disaster and can be explored through a short- or long-term perspective. This illustrates the complexity of the relationship between environmental disasters and migration. 
The variation of findings consequently raises various questions. The first one relates to the engagement of governments and public services in their work to assist people facing adverse environmental shocks. Indeed, if people only rely on migrants to help them to deal with shocks, what about those who do not have migrants in their households? This raises some important equity issues. The more vulnerable probably have fewer migrants in their households and thus are more exposed during shocks. One possibility would be to better coordinate public and private funds from migrants in order to have overall better management. The second issue is related to the research perspective. There is a need to better identify who exactly migrates when environmental disasters occur. It is also important to know whether remittances are sufficient enough to deal with shocks in the long term. This opens future avenues for research related to environmental disasters and migration. 


\section{References}

Amuedo-Dorantes, C.; Pozo, S. \& Vargas-Silva, C. (2010), 'Remittances in Small Island Developing States', The Journal of Development Studies 46(5), 941-960.

Arouri, M.; Nguyen, C. \& Youssef, A. B. (2015), 'Natural Disasters, Household Welfare, and Resilience: Evidence from Rural Vietnam', World Development 70, 59--77.

Beine, M. \& Parsons, C. (2015), 'Climatic factors as determinants of International Migration', The Scandinavian Journal of Economics 117(2), 723--767.

Belasen, A. R. \& Polachek, S. W. (2013), Natural disasters and migration, Edward Elgar Publishing, Inc., Cheltenham, UK.

Black, R. (2001), Environmental refugees: myth or reality?, Vol. 34, UNHCR.

Boustan, L. P.; Kahn, M. E. \& Rhode, P. W. (2012), 'Moving to higher ground: migration response to natural disasters in the early twentieth century', The American Economic Review, 238--244.

Combes, J.-L. \& Ebeke, C. (2011), 'Remittances and Household Consumption Instability in Developing Countries', World Development 39(7), 1076-1089.

Deng, Q. (2011), 'Natural disasters, migration and urban insecurity in China',.

Drabo, A. \& Mbaye, L. M. (2013), 'Natural disasters, migration and education: an empirical analysis in developing countries', Environment and Development Economics, 1--30.

Enarson, E. P. (2000), Gender and natural disasters, ILO Geneva.

Fagen, P. W. (2006), 'Remittances in conflict and crises: How remittances sustain livelihoods in war, crises and transitions to peace', .

Findley, S. E. (1994), 'Does Drought Increase Migration? A Study of Migration from Rural Mali during the 1983-1985 Drought', International Migration Review 28(3), pp. 539-553.

Ghimire, R.; Ferreira, S. \& Dorfman, J. H. (2015), 'Flood-induced displacement and civil conflict', World Development 66, 614--628.

Gray, C. \& Mueller, V. (2012), 'Drought and Population Mobility in Rural Ethiopia', World Development 40(1), 134 - 145.

Gray, C. L. (2009), 'Environment, land, and rural out-migration in the southern Ecuadorian Andes', World Development 37(2), 457--468.

Guha-Sapir, D.; Hoyois, P. \& Below, R. (2013), Annual Disaster Statistical Review 2012: The Numbers and Trends. CRED, Université catholique de Louvain, Brussels.

Gutmann, M. P. \& Field, V. (2010), 'Katrina in historical context: Environment and migration in the US', Population and environment 31(1-3), 3--19. 
Halliday, T. (2006), 'Migration, Risk, and Liquidity Constraints in El Salvador', Economic Development and Cultural Change 54(4), pp. 893-925.

Henry, S.; Schoumaker, B. \& Beauchemin, C. (2004), 'The impact of rainfall on the first outmigration: A multi-level event-history analysis in Burkina Faso', Population and Environment 25(5), 423--460.

Hornbeck, R. (2012), 'The Enduring Impact of the American Dust Bowl: Short- and Long-Run Adjustments to Environmental Catastrophe', American Economic Review 102(4), 1477-1507.

Jackman, M. (2013), 'Macroeconomic Determinants of Remittance Volatility: An Empirical Test', International Migration 51(s1), e36--e52.

Marchiori, L.; Maystadt, J.-F. \& Schumacher, I. (2012), 'The impact of weather anomalies on migration in sub-Saharan Africa', Journal of Environmental Economics and Management 63(3), 355-374.

Mohapatra, S.; Joseph, G. \& Ratha, D. (2012), 'Remittances and natural disasters: ex-post response and contribution to ex-ante preparedness', Environment, Development and Sustainability 14(3), 365--387.

Naudé, W. (2010), 'The Determinants of Migration from Sub-Saharan African Countries-super†', Journal of African Economies 19(3), 330-356.

Neumayer, E. \& Plümper, T. (2007), 'The gendered nature of natural disasters: The impact of catastrophic events on the gender gap in life expectancy, 1981-2002', Annals of the Association of American Geographers 97(3), 551--566.

Piguet, E. \& Pecoud, A. (2011), Migration and climate change, Cambridge University Press.

Rosenzweig, M. R. \& Stark, O. (1989), 'Consumption smoothing, migration, and marriage: Evidence from rural India', The Journal of Political Economy, 905--926.

Savage, K. \& Suleri, A. (2006), 'Remittances in Crises: A Case Study from Pakistan', Overseas Development Institute (ODI).

Schultz, J. \& Elliott, J. R. (2013), 'Natural disasters and local demographic change in the United States', Population and Environment 34(3), 293--312.

Stark, O. \& Levhari, D. (1982), 'On migration and risk in LDCs', Economic development and cultural change, 191--196.

Vigdor, J. (2008), 'The economic aftermath of Hurricane Katrina', The Journal of Economic Perspectives 22(4), 135--154.

Yang, D. \& Choi, H. (2007), 'Are Remittances Insurance? Evidence from Rainfall Shocks in the Philippines', World Bank Economic Review 21(2), 219-248. 
Figures: Trends of Natural Disasters and Migrant Stocks from Low and Lower Middle Income Countries ${ }^{i}$

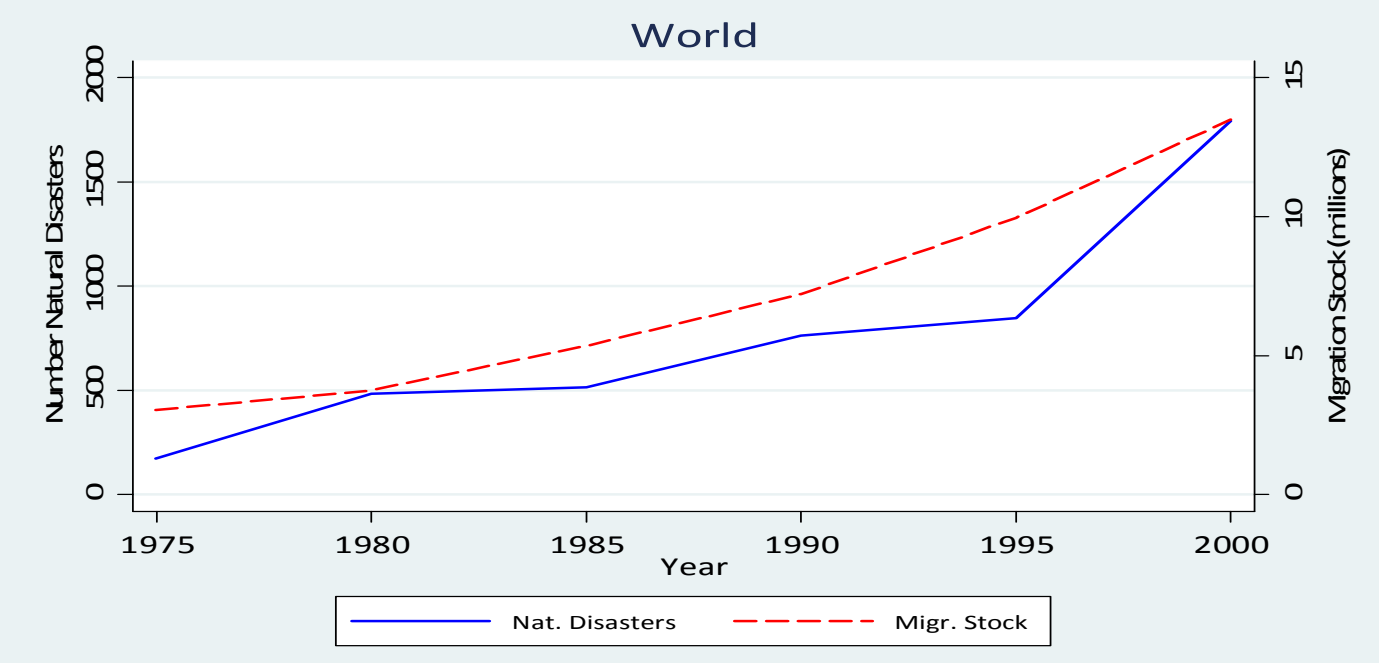

Source: Authors' construction based on data from CRED, and Schiff and Sjöblom (2008)
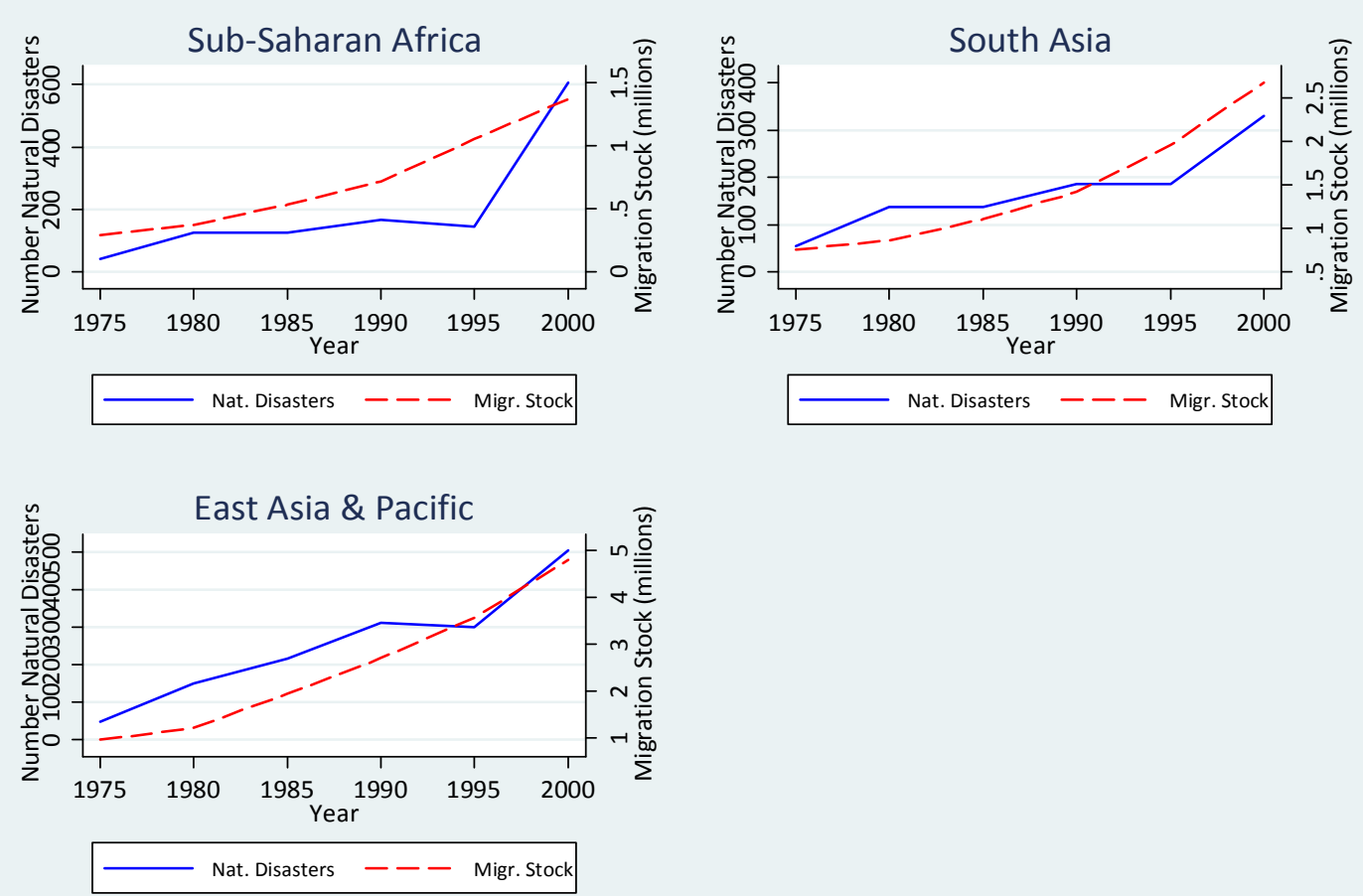

Source: Authors' construction based on data from CRED, and Schiff and Sjöblom (2008) 

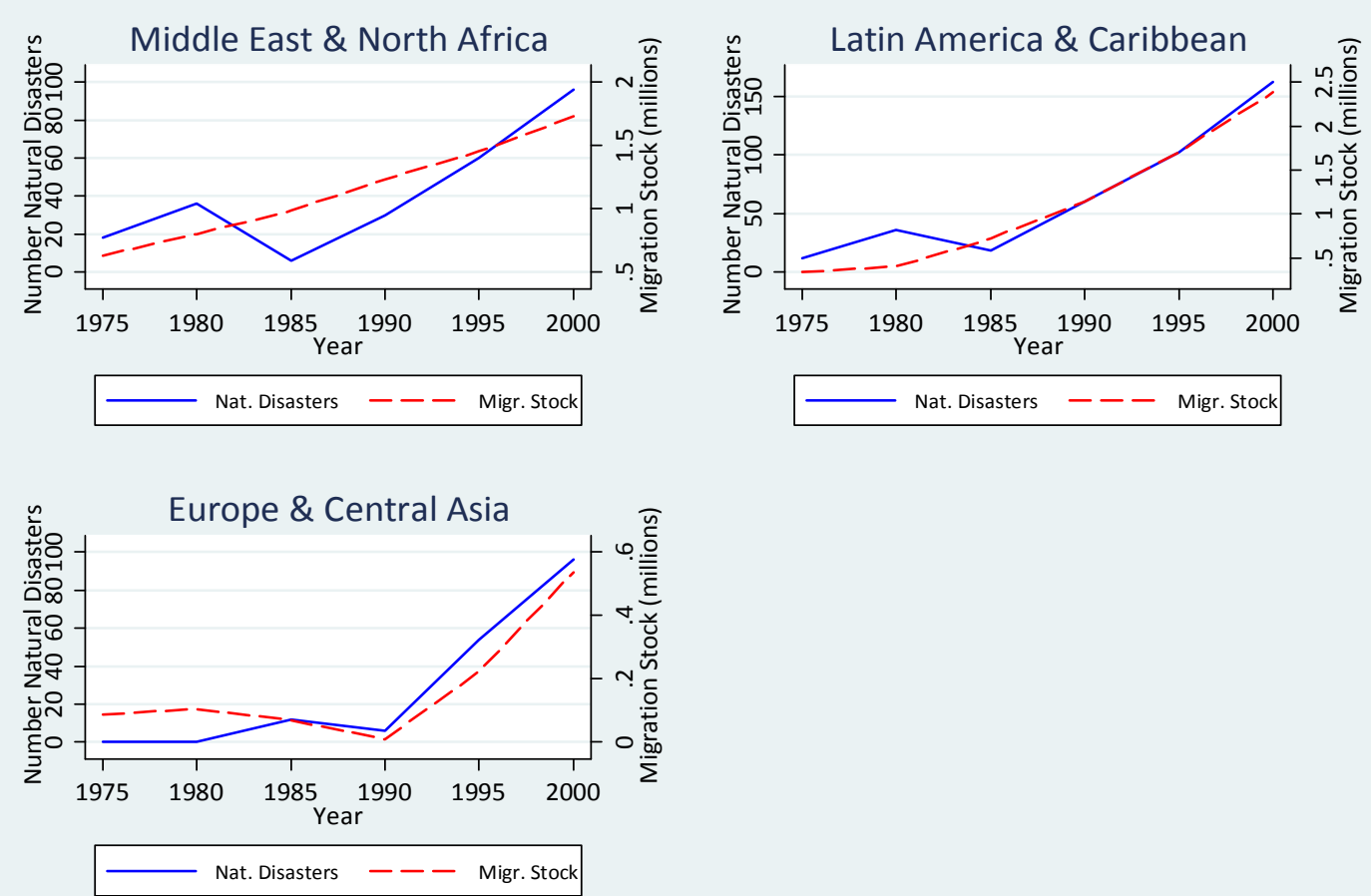

Source: Authors' construction based on data from CRED, and Schiff and Sjöblom (2008)

Source: Drabo and Mbaye (2013)

\footnotetext{
' These figures are from Drabo and Mbaye (2013). In Drabo and Mbaye (2013), number of natural disasters represents the number of natural disasters over the period 1975-2000 and which are related to climate change such as meteorological disasters (storms), hydrological disasters (floods, and other wet mass-movements) and climatological disasters (drought, wildfire and extremely high temperatures). For the migration variable, emigration rates are calculated as the stocks of migrants from origin countries to the six main destination countries (Australia, Canada, France, Germany, the UK and the United States) for low, medium and high education levels, divided by the stock of people over 25 years old corresponding to the same education level in the origin country, plus the stock of migrants of the sending countries.
} 